\title{
Top Grafting Performance of Some Cocoa (Theobroma cacao L.) Clones as Affected by Scion Budwood Number
}

\author{
Fakhrusy Zakariyya ${ }^{1 *}$ and Fitria Yuliasmara ${ }^{1)}$ \\ ${ }^{1)}$ Indonesian Coffee and Cocoa Research Institute, Jl. PB. Sudirman 90, Jember Indonesia \\ ${ }^{*}$ Corresponding author: fakhrusy.zakariyya@gmail.com \\ Received: 13 November 2015 / Accepted: 27 November 2015
}

\begin{abstract}
Reducing budwood number is an efficient effort to overcome problems related with limited scion materials. The objective of this research was to study the effect of scion budwood number in some clones on the performance of grafted cocoa seedlings. The research was conducted at Kaliwining Research Station, Indonesian Coffee and Cocoa Research Institute, Jember, Indonesia at an elevation of $48 \mathrm{~m}$ above sea level. Layout for this study used factorial with 2 factors in randomized complete block design, with four replications for every treatment. The first factor was clone type, namely MCC 02 and Sulawesi 1; whereas the second factor was number of grafted scion budwood, namely one, two, and three grafted budwoods. There was no interaction between clone and number of scion budwood for variables of shoot length, stem girth, content of total chlorophyll, chlorophyll $a$, and chlorophyll b. Meanwhile, there was interaction for stomatal conductance and stomatal diffusion resistance. Clone significantly affected photosynthesis and stomatal diffusion resistance, while number of scion budwood affected significantly the shoot length. Photosynthesis activity of MCC 02 was higher compared to Sulawesi 1. In average, stomatal diffusion resistance of Sulawesi 1 was higher than MCC 02. The shoot length of one grafted budwood was higher than the two or three grafted budwood.
\end{abstract}

Keywords: top grafting, budwood, clones, cocoa, Theobroma cacao, photosynthesis

\section{INTRODUCTION}

Top grafting is the most common method used in cocoa plant propagation which is aimed to obtain a superior trait combination between two parents by clonal method. Principally, that method combines scion (budwood) with rootstock which merges the cambium of scion and rootstock.

Cocoa's top grafting has some advantages such as obtaining new plant which has the same trait with its parents, fast growing, early precosity, cheap, simple, well-developed roots, and combining superior traits from its parents. On the other hand, disadvantage of this method is rootstock-scion incompatibility. Difference in rootstock and scion affects cocoa production and plant growth vigour (Prawoto, 2008; Pang-Thau-Yin, 2004). It has been reported that survival rate of grafted scions could reach $80 \%$ in condition where air temperature $27.7^{\circ} \mathrm{C}$ with relative humidity (RH) 76.2\% (Prawoto, 2007). Previous study carried out by Anitasari \& Susilo (2012) has reported grafting performance of some scion clones and root-stock family on cocoa. 
Supply of rootstock highly depends on the availibility of cocoa seeds, meanwhile the availability of scions depend on number of scion budwood which derived from plagiotrophic branches. On the other hand, plagiotrophic branches are the places of mostly growing cocoa pods; therefore, the branch availability is limited by some factors. Taking of budwoods from selected superior trees should be done either in the early or the end of rainy season. Meanwhile, taking out of budwood from productive farms should be done in limited number considering that it may affect plant production. Application of grafting in cocoa nursery may last for six months considering that the seedlings will be planted in the beginning of the rainy season. Seeds for rootstock are planted in June while taking budwood for scion material is carried out in August. Meanwhile, recommended minimum number of scion budwood is three budwoods for each grafting. However, need for budwoods especially in large quantities in limited period is a challenge for cocoa nursery planters when using top grafting method. In the case of cashew plants, the number of grafted scion budwoods affected shoot length, number of leaves and percentage of flowers bearing fruits, as reported by Suharto (2012). Reducing budwood number is an effort to overcome problems in limited scion materials. The objective of this research was to study the effect of scion budwood number in some cocoa clones on their seedling performances.

\section{MATERIALS AND METHODS}

The research was conducted in Kaliwining Research Station, Indonesian Coffee and Cocoa Research Institute, Jember, Indonesia at an elevation of $48 \mathrm{~m}$ above sea level. The soil in the experimental site is classified as Inceptisol, with D climate type based on Schmidt \& Fergusson classification.

The layout for this study used factorial with two factors in randomized complete block design, with four replications for every treatment. Each plot consisted of five top grafted cocoa (Theobroma cacao L.) seedlings. The first factor was cocoa clone types, namely MCC 02 and Sulawesi 1. The second factor was number of scion budwoods, namely 1 , 2, and 3 budwoods per rootstock (Figure 1).

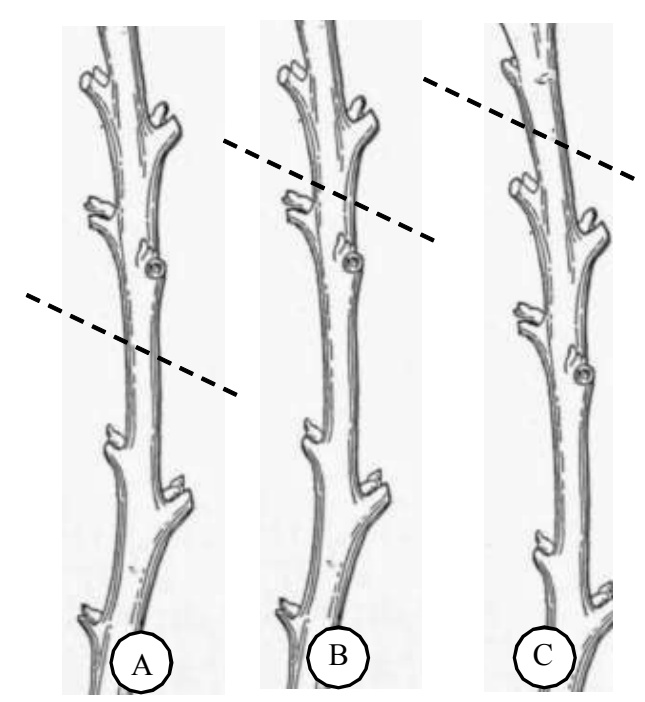

Figure 1. Number of scion budwoods, namely three (A), two (B), one (C) 
Four months old rootstock derived from Sulawesi 1 clone with open pollinated seeds. Nursery maintenance was conducted according to standard operational procedure, including fertilizing, pruning and controlling of pests and diseases.

The observed parameters were live budwood percentage, shoot length, stem girth, stomatal conductance, photosynthesis rate, and stomatal diffusion resistance. Stomatal diffusion resistance and stomatal conductance were observed using a leaf porometer (Decagon ${ }^{\circledR}$, USA) referred to Zakariyya \& Prawoto (2015).

Photosynthesis activity was measured using Photosynthesis Yield Analyzer (Mini$\mathrm{PAM}^{\mathbb{R}}$ ) which was tagged on cocoa leaves, namely third youngest, fully expanded and fully hardened leaves, because those leaves are the most physiologically active (Daymond et al., 2011). Measurement using Mini-PAM ${ }^{\circledR}$ was conducted by tagging a detector to the adaxial leaves. Content of total chlorophyll, chlorophyll a, and chlorophyll b were measured using SPAD-502. The equation for calculating the content of chlorophyll a, chlorophyll b and total chlorophyll referred to the research conducted by Netto et al. (2007). The equations to calculate chlorophyll $\mathrm{a}, \mathrm{b}$ and total were: chlorophyll a: $\mathrm{Y}=15,5866+1,0338 \mathrm{X}$ $+0,0679 \mathrm{X}^{2}$; chlorophyll b: $\mathrm{Y}=30,1471-$ $0,4592 X+0,0270 X^{2}$; total chlorophyll: $\mathrm{Y}=$ $44,5885+0,7188 \mathrm{X}+0,0933 \mathrm{X}^{2}$. $\mathrm{Y}$ is content of chlorophyll (a, b, or total) and $\mathrm{X}$ was SPAD-502 reading. Chlorophyll a, $\mathrm{b}$ and total were expressed in $\mu$ mol. $\mathrm{m}^{-2}$ unit. Data analysis used Excel and SPSS 14.

\section{RESULTS AND DISCUSSION}

Based on this research results, variance analysis showed that clones affected stomatal diffusion resistance and photosyntesis activity (Fv/Fm). Meanwhile, budwood number influenced shoot length. However, their interaction affected stomatal diffusion resistance and stomatal conductance (Table 1).

Table 1. Analysis of variance of stem girth, shoot length, total chlorophyll $(a+b)$, chlorophyll $a$, chlorophyll $b$, stomatal diffusion resistance, photosynthesis activity $(\mathrm{Fv} / \mathrm{Fm})$ as affected by clone and number of scion budwood and their interaction

\begin{tabular}{lccc}
\hline Budwood parameters & Clones & Scion budwood numbers & Interaction \\
\hline Stem Girth & $1,86 \mathrm{~ns}$ & $0,34 \mathrm{~ns}$ & $0,96 \mathrm{~ns}$ \\
Shoot Length & $0,01 \mathrm{~ns}$ & $6,9 *$ & $1,21 \mathrm{~ns}$ \\
Total chlorophyll & $4,15 \mathrm{~ns}$ & $1,22 \mathrm{~ns}$ & $0,62 \mathrm{~ns}$ \\
Chlorophyll a & $4,08 \mathrm{~ns}$ & $1,21 \mathrm{~ns}$ & $0,63 \mathrm{~ns}$ \\
Chlorophyll b & $4,47 \mathrm{~ns}$ & $1,25 \mathrm{~ns}$ & $0,61 \mathrm{~ns}$ \\
Stomatal diffusion resistance & $5,88 *$ & $2,72 \mathrm{~ns}$ & $6,55 *$ \\
Fv/Fm & $21,73 *$ & $0,14 \mathrm{~ns}$ & $0,11 \mathrm{~ns}$ \\
Stomatal Conductance & $4,34 \mathrm{~ns}$ & $1,56 \mathrm{~ns}$ & $5,39 *$
\end{tabular}


The result showed that the treatments had difference in life percentages of grafted cocoa seedling (Figures 2), where for MCC 02 clone was higher than Sulawesi 1 clone. Rootstocks grafted with three scion budwoods had higher life percentages than other treatments. However, higher life percentage was obtained in MCC 02 clone grafted with three budwoods than Sulawesi 1 clone with the same number of scion budwood. Meanwhile, on grafting seedlings, the smallest viability was shown by Sulawesi 1 clone with two budwoods of scion, namely
$45 \%$, then followed by those clones with a budwood, i.e. $55 \%$, despite they showed no significantly difference each other. On MCC 02 clone, grafting by using one and two budwoods consistently gave high life percentages which were $75 \%$ and $80 \%$, respectively. Based on Anita-Sari \& Susilo (2012) work, Sulawesi 1 was grouped in medium viability.

Budwoods are needed as food reservation for early growth of seedlings. Based on the research, number of scion budwood affected the success of grafting seedling

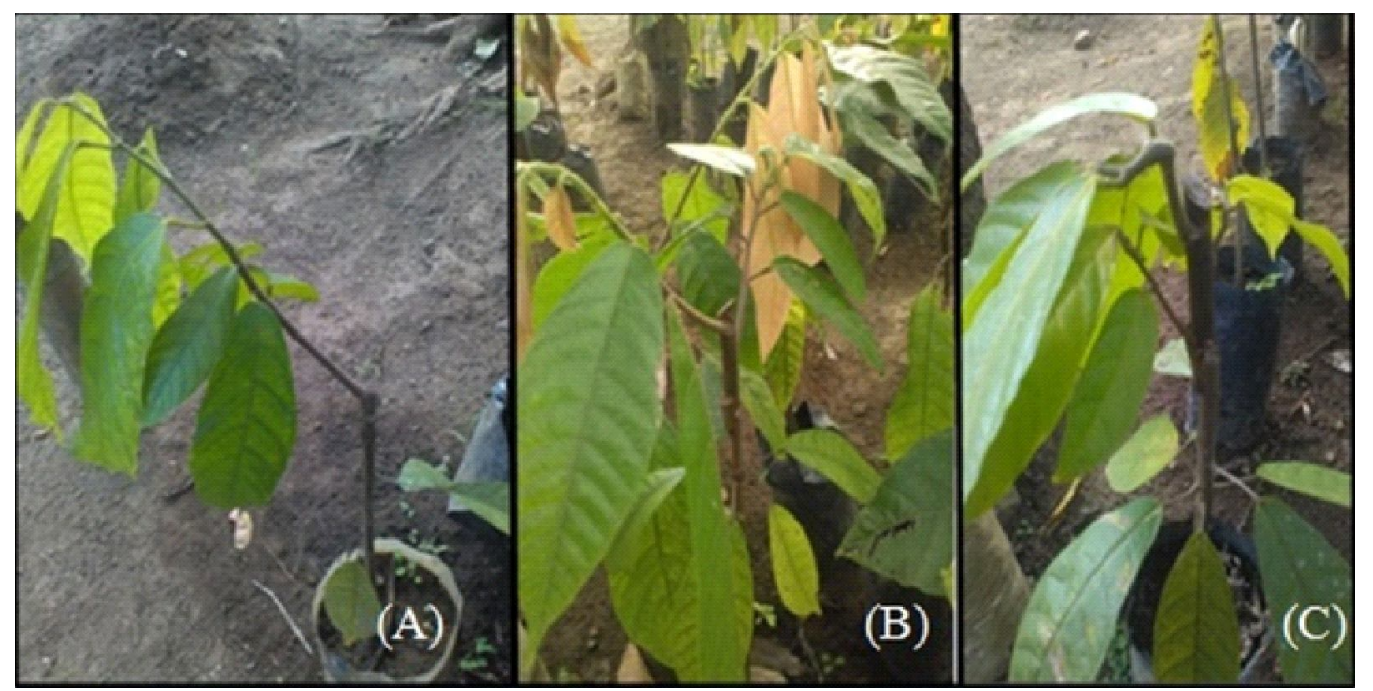

Figure 2. Performance of cocoa seedlings grafted with one budwood (A); two budwoods (B); and three budwoods $(\mathrm{C})$ of scion.

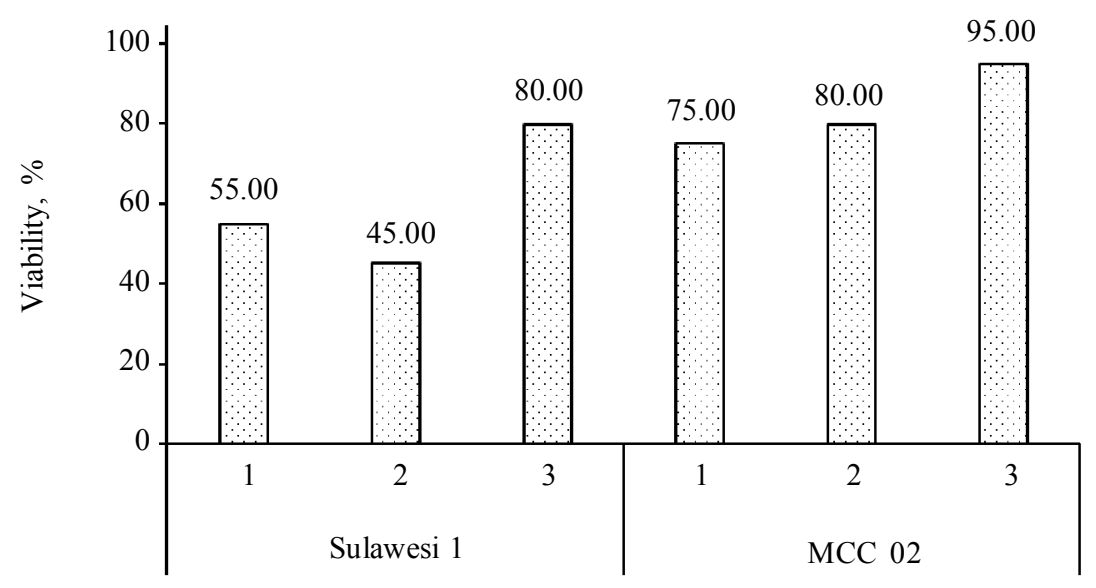

Figure 3. Viability of Sulawesi 1 and MCC 02 clones with different the number of scion budwood. 
viability. Risk of minimum budwood number is no substituted shoots which can be maintained when the other shoot was attacked by Phytopthora palmivora disease and Helopeltis sp., dry bud risk, and the occurrence of other physical disorders. Helopeltis becomes a serious problem in the process of grafting in seedling stage. Helopeltis attacks and inhibits shoot growth as a result the leaves become dry (Atmadja, 2003; Santoso et al., 2013). Bahri \& Santoso (2013) reported that for cassava cutting needed at least two buds. Seedlings with less than two buds was vulnerable to drought and less viability. Therefore, special handling is neccesary related to its treatment e.g. pest control, fertilization, and others to optimize the seedling vigour.

\section{Shoot length}

A single factor of clone did not significantly affect shoot length; meanwhile, number of scion budwood significantly affected that parameter (Table 2). The highest shoot length was obtained from grafting with one budwood. Grafting with two and three budwoods showed significant difference compared with one budwood. Number of budwoods reflects different scion length, meaning that the more budwood number was, the longer scion size would be.

Waluya (2011) reported that on cassava cutting, the higher number of scion budwoods is, the higher number of shoots will appear. Thus, the consumption of food reservation in plant will be higher and may compete each others. In another case, the differences of budwood size in grafting have been attributed to the change of shoot concentrations of phytohormones, such as auxin, gibberellin, absisic acid, and cytokinin (Grochowska et al., 1984; Kamboj et al., 1998; Kamboj et al., 1999; Steffens \& Hedden, 1992).

\section{Shoot Girth}

According to Table 3, shoot girth was not different among the treatments, either clones or number of scion budwoods. In general, shoot girth of MCC 02 was greater than Sulawesi 01, even though it was not significantly different. Scion which is highly compatible with rootstocks and has well graft union will support translocation of assimilation, water, nutrients, hormones and enzimes to the whole seedlings. Initiation of morphogenic scions by grafting induces morphological changes on leaves, flowers and fruits due to

Table2. Effects of clones and number of scion budwoods on shoot length of grafted seedling

\begin{tabular}{|c|c|c|c|}
\hline Clones & Shoot length, cm & Scion budwoods number & Shoot length, $\mathrm{cm}$ \\
\hline Sulawesi 1 & $11.8 \mathrm{a}$ & 1 & $14.8 \mathrm{a}$ \\
\hline \multirow[t]{2}{*}{ MCC 02} & $11.7 \mathrm{a}$ & 2 & $8.4 \mathrm{~b}$ \\
\hline & & 3 & $12.1 \mathrm{ab}$ \\
\hline
\end{tabular}
Duncan test.

Table 3. Effects of clones and number of scion budwoods on shoot girth of grafting seedling

\begin{tabular}{lccc}
\hline Clones & Shoot girth $(\mathrm{cm})$ & Scion budwoods number & Shoot girth $(\mathrm{cm})$ \\
\hline Sulawesi 1 & $1.1 \mathrm{a}$ & 1 & $1.2 \mathrm{a}$ \\
MCC 02 & $1.3 \mathrm{a}$ & 2 & $1.1 \mathrm{a}$ \\
& & 3 & $1.3 \mathrm{a}$
\end{tabular}

Note: Numbers within the same column followed by the same letter are not significantly different at $5 \%$ level according to Duncan test. 
genetic changes which have potential in genetic improvement (Eltayb, 2014).

In general, the number of budwoods (scion) which were grafted to the rootstocks grew similarly. However, different number of scion budwood did not consistenly affect shoot girth. In the field, scion growth can be vary with the predicted size from the rootstocks to which they are grafted. It may be affected by environmental factors. Tworkoski \& Fazio (2011) reported that various size of apple fuji scions which were grafted to the same rootstocks size grow uniformly, but there was a modification of xylem sap size.

According to Sukarmin et al. (2009), food reservation which is accumulated into rootstocks is formed by photosynthesis process and required to support the callus initiation on graft union as well as to stimulate budwood dormancy to break and then grow. Suharsi (2013) found that the readiness of root stock to be grafted on scion associated with the age and size of the rootstock. The older and larger rootstock is, the better stem growth stimulation will be.

\section{Chlorophyll a, b, and total}

Chlorophyll is a pigment which has a main function to support photosynthesis. Based on this research, the total chlorophyll, chlorophyll $\mathrm{a}$ and $\mathrm{b}$ were not different significantly. Based on clone and number of budwood, MCC 02 has higher chlorophyll than Sulawesi 01. The treatment grafting by three budwoods showed the highest content in total chlorophyll, chlorophyll $\mathrm{a}$ and $\mathrm{b}$. Chlorophyll a is dark green color pigment and chlorophyll $\mathrm{b}$ is green color pigment and they absorb red color (Ai \& Banyo, 2011). However, the function of chlorophyll in photosynthesis process transforms light energy into chemical energy of ATP (adenosine triphosphate) and NADPH (nicotinamide adenine dinucleotide phosphate $+\mathrm{H}$ ), which occurs in the light reactions. Furthermore, the chemical energy used in the dark reactions reduces $\mathrm{CO}_{2}$ into carbohydrates and $\mathrm{O}_{2}$ (Salisbury \& Ross, 1995).

Generally, grafting method has been reported to be able to affect some physiological characteristics especially chlorophyll and photoshyntesis performance (Ballesta et al, 2010). Some researchers have confirmed that compatibility of rootstocks-scion grafting tends to enhance plant fruit quality in some ways (Lee et al., 2003; Angela et al., 2008; Li et al., 2009). Chlorophyll content in musk mellon plant increased in grafting treatments which had impacts on photosyntesis process and carbohydrates content (Liu et al., 2011). However, the increase in photosynthesis and carbohydrate metabolism due to grafting has the potential to improve plant quality.

Table 4. Effects of clones and number of scion budwoods on total chlorophyll, chlorophyll a and b content

\begin{tabular}{lcccc}
\hline Clones & $\begin{array}{c}\text { Scion budwoods } \\
\text { number }\end{array}$ & $\begin{array}{c}\text { Total chlorophyll } \\
\left(\mu \mathrm{mol} . \mathrm{m}^{-2}\right)\end{array}$ & $\begin{array}{c}\text { Chlorophyll a } \\
\left(\mu \mathrm{mol}^{-2}\right)\end{array}$ & $\begin{array}{c}\text { Chlorophyll b } \\
\left(\mu \mathrm{mol} . \mathrm{m}^{-2}\right)\end{array}$ \\
\hline MCC 02 & 1 & $180.7 \mathrm{~ns}$ & $132.2 \mathrm{~ns}$ & $46.7 \mathrm{~ns}$ \\
& 2 & $170.9 \mathrm{~ns}$ & $123.8 \mathrm{~ns}$ & $45.4 \mathrm{~ns}$ \\
Sulawesi 1 & 3 & $229.9 \mathrm{~ns}$ & $171.0 \mathrm{~ns}$ & $57.0 \mathrm{~ns}$ \\
& 1 & $139.5 \mathrm{~ns}$ & $99.1 \mathrm{~ns}$ & $38.8 \mathrm{~ns}$ \\
& 2 & $157.2 \mathrm{~ns}$ & $113.4 \mathrm{~ns}$ & $42.0 \mathrm{~ns}$ \\
\hline
\end{tabular}

Note: $n s=$ not statistically significant at $5 \%$ level according to Duncan test. 


\section{Photosynthesis (Fv/Fm)}

The value of photosynthesis can be expressed in $\mathrm{Fv} / \mathrm{Fm}$ units. The value of $\mathrm{Fv} /$ $\mathrm{Fm}$ is flouresence value which indicates the maximum photochemical efficiency of Photosystem II or the maximum photochemical energy conversion (Lamontagne et al., 2000; Heinz-Walz-GmbH, 1999). The maximum quantum yield $(\mathrm{Fv} / \mathrm{Fm})$ can be estimated by measuring the increase in fluorescence yield from dark-adapted minimal fluorescence (Fo) to maximal fluorescence $(\mathrm{Fm})$, which is associated with the closing of photosynthetic reaction centers during light saturation or a photosynthetic inhibitor such as 3'-(3,4-dichlorophenyl)-1',1'dimethyl urea (DCMU) (Cullen et al., 1979).

As presented in Table 5, photosynthetic rate showed significant difference between the clones tested, however number of scion budwood treatment has no significant effect. MCC 02 was significantly different from Sulawesi 1 . The value of $\mathrm{Fv} / \mathrm{Fm}$ diversely ranged from 0,2 to 0,7 (Heinz Walz GmbH, 1999). However, the variations of $\mathrm{Fv} / \mathrm{Fm}$ ratio appeared to be related with biomass and independent assimilation. It means that for $\mathrm{Fm}$ and $\mathrm{Fv} / \mathrm{Fm}$ parameters, the response is complex, not only related to chlorophyll a concentration, but also to light scattering and re-absorption phenomenon (Ting \& Owens, 1992; Büchel \& Wilhelm, 1993).

The clones of cocoa grafting seedling performed differently for photosyntesis.
These results were in agreement with the study by Zheng et al. (2009) who have found that grafting reduced damage on photosynthetic apparatus. A similar effect was observed when grafting tomato plant with a salt tolerant rootstock, since it maintained higher photochemical activity of photosystem II (He et al., 2009). According to their research result, Albacete et al. (2009) reported an induced rootstock increased crop productivity toward changes in leaf area and photosynthetic capacity. On the other hand, photosystem II contained chlorophyll a which highly absorbs solar energy with $680 \mathrm{~nm}$ of wave length.

\section{Stomatal Conductance and Stomatal Diffusion Resistance}

Figure 4 presents a significant interactions between clone and number of scion budwood to stomatal conductance parameter. Stomatal conductance is conductive ability of stomata for gas movement from high to low concentration, meanwhile stomatal resistance is the inhibition of gases to enter through the stomata (Salisbury \& Ross, 1995). Drake et al. (2013) reported that stomatal characters affected the mechanism of gas exchange (including $\mathrm{CO}_{2}$ ) in the plant especially on leaves. $\mathrm{CO}_{2}$ is required in the photosynthesis process, therefore stomatal conductance will be important in obtaining an optimum performance for grafting seedling.

Table 5. Effects of clones and number of scion budwoods on the content of total chlorophyll, chlorophyll a and b

\begin{tabular}{lccc}
\hline Clones & $\mathrm{Fv} / \mathrm{Fm}$ & Scion budwood number & $\mathrm{Fv} / \mathrm{Fm}$ \\
\hline Sulawesi 1 & $0.40 \mathrm{~b}$ & 1 & $0.41 \mathrm{a}$ \\
MCC 02 & $0.42 \mathrm{a}$ & 2 & $0.41 \mathrm{a}$ \\
& & 3 & $0.41 \mathrm{a}$
\end{tabular}

Note: Numbers within the same column followed by the same letter are not significantly different at $5 \%$ level according to Duncan test. 
On MCC 02 clone, rootstocks which were grafted to various numbers of scion budwoods performed no significant difference to each other. Meanwhile, several budwoods of Sulawesi 1 grafted seedling were not significantly different. The highest value was obtained on MCC $02\left(17,0 \mathrm{mmol} / \mathrm{m}^{2} \mathrm{~s}\right)$ grafted with single bud scion and was different significantly compare to Sulawesi $1(12,4$ $\mathrm{mmol} / \mathrm{m}^{2} \mathrm{~s}$ ) with single bud scion. Higher number of scion budwood reduced stomatal conductance even though it had small corellation $\left(\mathrm{R}^{2}=1,992\right)$. It was the contribution of size of budwoods together with number of scion budwood which increased the effort to transport nutrients. Higher bud size caused lower transpiration and stomatal conductance.

Stomatal diffusion resistance caused reverse effect compared with stomatal conductances and this parameter was also affected by interaction among treatments. The value of stomatal diffusion resistance on MCC 02 was relatively lower than Sulawesi 1 . The highest value was obtained on Sulawesi 01 grafted with one budwood $\left(81,38 \mathrm{~m}^{2} / \mathrm{mmol}\right)$ and significantly different to MCC 01 at the same number of grafted scion budwood. The higher the value of stomatal resistance is, the lower the gas (included $\mathrm{CO} 2$ ) diffusion barrier will enter the leaves, so that photosynthesis will be smaller (Zakariyya \& Prawoto, 2015).

In some studies, grafting method was reported to be able to modify xylem sap (Ballesta, 2010; Johkan, 2009). Meanwhile, the compatibility of scion-rootstock may determine water and nutrient translocation and affect other physiological traits (Ballesta, 2010; Omid et al., 2007). Johkan (2009) found that grafting old sweet pepper plants resulted in poor development in their xylem connections at the graft site, which results in low stomatal resistance and water potential compared to younger plants. Some studies reported that scion and number of scion budwood affected stomatal performance, which produced higher $\mathrm{CO}_{2}$ assimilation rate and less stomatal resistance than in non-grafted and/or self-grafted plants (Yetisir et al., 2007; Rouphael et al., 2008; He et al., 2009; Zheng et al., 2009).

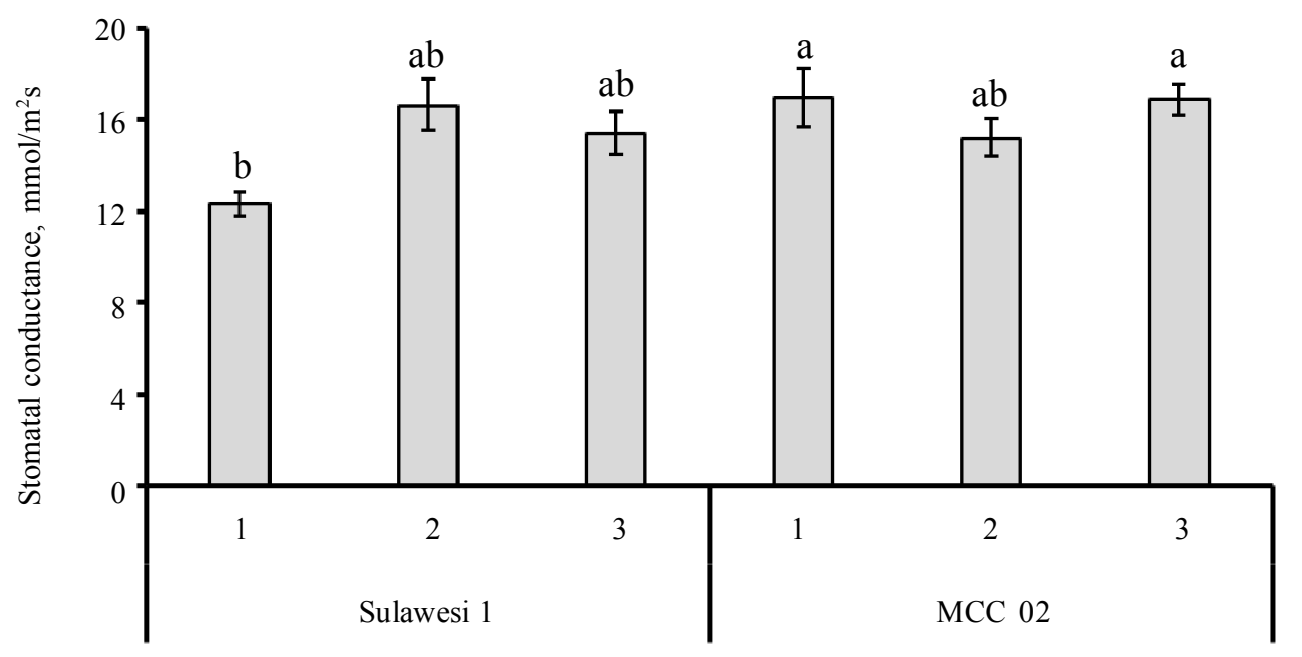

Figure 4. Effects of cocoa clones and number of scion budwood to stomatal conductance 


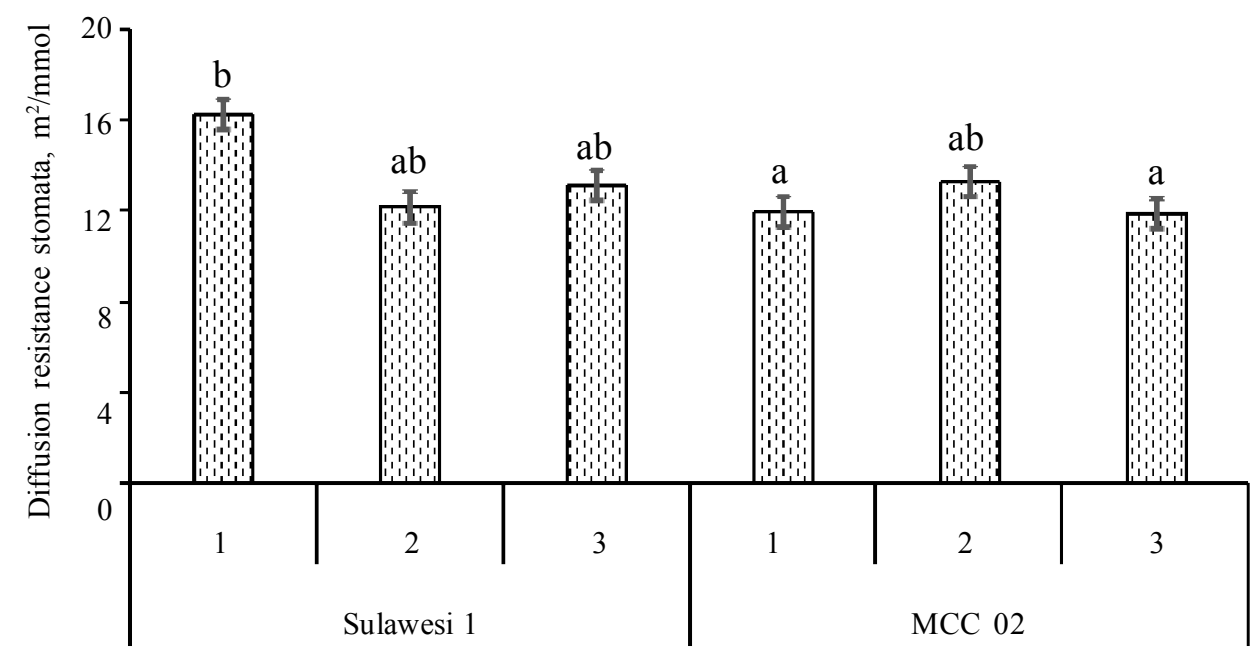

Figure 5. Effect of cocoa clones and number of scion budwood to stomatal diffusion resistance

\section{CONCLUSION}

Clone and number of scion budwood interaction generate no significant difference for parameters of shoot length, shoot girth, total chlorophyll, chlorophyll a, and chlorophyll b. Meanwhile, stomatal conductance and stomatal diffusion resistance showed significant effects. Single factor of clone provided significant effects on photosynthesis and stomatal diffusion resistance, while number of grafted scion budwoods gave a significant effect on shoot length. The best treatment was obtained from MCC 02 grafted with 3 budwoods which had the highest life percentage (95\%). MCC 02 grafted with one, two, or three of scion budwoods had the highest $\mathrm{Fv} / \mathrm{Fm}$ and stomatal conductance. On Sulawesi 1, the best treatment was obtained from three budwoods.

\section{ACKNOWLEDGEMENT}

The authors thank to Dr. Misnawi and Dr. Agung Wahyu Susilo as supervisors. We also thank to Mr. Soedradjad and Mr. Herwanto who supported this research.

\section{REFFERENCES}

Ai, N.S. \& Y. Banyo (2011). Konsentrasi klorofil daun sebagai indikator kekurangan air pada tanaman. Jurnal Ilmiah Sains, 11, 2, 166-173.

Angela, R.; Davis \& P. Pertain-Vazie (2008). Grafting effect on vegetable quality. Horticulture Science., 43, 167-175

Anita-Sari, I. \& A.W. Susilo (2012). Keberhasilan sambungan pada beberapa jenis batang atas dan famili batang bawah kakao (Theobroma cocoa L.). Pelita Perkebunan, 28, 72-81.

Albacete, A.; C. Martínez-Andújar; M.E. Ghanem; M. Acosta; J. Sánchez-Bravo; M.J. Asins; J. Cuartero; S. Lutts; I.C Dodd \& F. PérezAlfocea (2009). Rootstock mediated changes in xylem ionic and hormonal status are correlated with delayed leaf senescence, and increased leaf area and crop productivity in salinized tomato. Plant Cell Environment, 32, 928-938.

Atmadja, W.R. (2003). Status Helopeltis antonii sebagai hama pada beberapa tanaman perkebunan dan pengendaliannya. Jurnal Litbang Pertanian, 22, 57-63.

Bahri, S. \& S.J. Santoso (2013) Perbanyakan tanaman ubi kayu (Manihot esculenta 
Crantz) dengan jumlah mata tunas pada varietas unggul Mekar Manik dan lokal. UEJS, 26, 1-10.

Ballesta, M.C.M.; C. Alcaraz-López; B. Muries, C. Mota-Cadenas \& M. Carvajal (2010). Physiological aspects of rootstockscion interactions. Scientia Horticulture, 127, 112-118.

Buchel, C. \& C. Wilhelm (1993). In vivo analysis of slow chlorophyll flourescence induction kinetics in algae: progress, problems and perspectives. Photochemistry Photobiology, 58, 137-148.

Cullen, J.J. \& E.H. Renger (1979). Continuous measurement of the DCMU-induced fluorescence response of natural phytoplankton populations. Marine Biology, 53, 13-20.

Daymond, A.J.; P.J. Tricker \& P. Hadley (2011). Genotypic variation in photosynthesis in cacao is correlated with stomatal conductance and leaf nitrogen. Biologia Plantarum, 55, 99-104.

Drake, P.L.; R.H. Froend \& P.J. Franks (2013). Smaller, faster stomata: scaling of stomatal size, rate of response, and stomatal conductance. Journal of Experimental Botany, 64, 495-505.

Eltayb, M.T.A.; T.D.A. Magid; A.A. Ibrahim \& A.M.A. Dirar (2014). Effect of grafting (rootstock) on morphological changes of scions in some acacia species. Journal of Forest Products \& Industries, 3, 27-36.

Grochowska, M.J.; G.J. Buta; G. L. Steffens \& M. Faust (1984). Endogenous auxin and gibberellin levels in low and high vigor apple. Acta Horticulture 146, 25-134.

He, Y.; Z.J. Zhu; J. Yang; X.L. Ni \& B. Zhu (2009). Grafting increases the salt tolerance of tomato by improvement of photosynthesis and enhancement of antioxidant enzymes activity. Environmental Experiments in Botany, 66, 270-278.
Heinz-Walz-GmbH. (1999). Photosynthesis Yield Analyzer MINI-PAM Portable Cholophyll Flourometer - Handbook of Operation. Einchenring, Germany.

Jaumein, F. \& M. Faust (1984). Stem anatomical structure of "Delicious" and "Golden Delicious" apple hybrids with various growth dynamics. Acta Horticulture, 147, 69-79.

Johkan, M.; K. Mitukuri; S. Yamasaki; G. Mori; M. Oda (2009). Causes of defolation and low survival rate of grafted sweet pepper plants. Scientia Horticulture, 119, 103-107.

Kamboj, J.S. \& J.D. Quinland (1998). The apple rootstock and its influence on endogenous hormones. Acta Horticultura, 463, 143-152.

Kamboj, J.S.; G. Brownong; P.S. Blake; J.D. Quinlan \& D.A. Baker (1999). GC-MS-SIM analysis of abscisic acid and indole-3acetic acid in shoot bark of apple rootstocks. Plant Growth Regulator, 28, 21-27.

Lamontagne, M.; F.J. Bigras \& H.A. Margolis (2000). Chlorophyll flouresence and $\mathrm{CO}_{2}$ assimilation of black spruce seedling following frost in different temperature and light condition. Tree Physiology Journal, 20, 249-255.

Lee, J.M. \& M. Oda (2003). Grafting of herbaceous vegetable and ornamental crops. Horticulture Review, 28, 61-124.

Li, Y.J.; G.Y. Liang \& X. Y. Liu (2009). Proteomic study on grafted and non-grafted cucumber (Cucumis sativus L.). Acta Hort Sinica, 36, 1147-1152.

Liu, Y.F.; H.Y. Qi; C. Bai; M. Qi; C. Xu; J. Hao; Y. Li \& T. Li (2011). Grafting helps improve photosynthesis and carbohydrate metabolism in leaves of muskmelon. International Journal of Biological Science, 7, 1161-1170.

Netto, A.; T.E. Campostrini., J.G. de Oliveira \& R.E. Bressan-Smith (2007). Photosythetic 
pigments, nitrogen, chlorophyll a fluorescence and SPAD-502 readings in coffee leaves. Science Horticulture 104, 199-209.

Omid, A.; T. Keilin \& A. Glass (2007). Characterization of phloem sap transcription profile in melon plants. Journal of Experimental Botany, 58, 3645-3656.

Pang-Thau-Yin, J. (2004). Rootstock effects on cocoa in Sabah, Malaysia. Experimental Agriculture, 40, 445-452.

Pudjiono, S. \& H.A. Adinugraha (2013) Pengaruh klon dan waktu okulasi terhadap pertumbuhan dan persentase hidup okulasi jati (Tectona grandis). Wana Benih, 14, 103-108.

Prawoto, A.A. (2008). Perbanyakan tanaman. In: Kakao: Manajemen Agrobisnis dari Hulu Hingga Hilir. Swadaya, Jakarta.

Prawoto, A.A. (2007). Review penelitian sambung samping pada kakao di Pusat Penelitian Kopi dan Kakao Indonesia, Jember. Prosiding Seminar Inovasi pada Lahan Marginal. Palu: 11-13 October 2007. pp 1-7.

Rouphael, Y.; M. Cardarelli; E. Reab \& G. Colla (2008). Grafting of cucumber as a mean to minimize copper toxicity. Environmental Experiments in Botany, 63, 49-58.

Salisbury, F.B. \& C.W. Ross (1995). Fisiologi Tumbuhan. Jilid dua: Biokimia Tumbuhan. ITB, Bandung.

Santoso, T.I.; Sudarsianto \& A.A. Prawoto (2013). Penggantian tajuk kakao (Theobroma cacao L.) untuk meningkatkan produktivitas dan ketahanan tanaman terhadap penyakit pembuluh kayu. Pelita Perkebunan, 29, 20-30.

Steffens, G.L. \& P. Hedden (1992). Comparison of growth and gibberelin concentrations in shoots from orchard-grown standard and thermosensitive dwarf apple trees. Plant Physiology, 86, 544-550.
Suharsi, T.K. \& A.D. Puspitasari (2013). Pertumbuhan mata tunas jeruk keprok (Citrus nobilis) hasil okulasi pada berbagai media tanam dan umur batang bawah rough lemon (C. jambhiri). Jurnal Ilmu Pertanian Indonesia, 18, 97-101.

Sukarmin; F. Ihsan \& Endriyanto (2009). Teknik perbanyakan FI mangga dengan menggunakan batang bawah dewasa melalui sambung pucuk. Buletin Teknik Pertanian, 14, 58-61.

Suharto, I.; G.A.A. Ambarawati; G.A.M.S. Agung \& G.M.O. Nurjaya (2012). The number of grafted scions and remaining productive branches affect new shoot growth and flowering of side-grafted cashew (Anacardium occidentale L.). Journal of International Society for Southeast Asian Agricultural Science, 18, 160-172.

Ting, C.S. \& T. G. Owens (1992). Limitations of the pulse-modulated technique for measuring the fluorescence characteristics of algae. Plant Physiology, 100, 367-373

Tworkoski, T. \& S. Miller (2007). Endogenous hormone concentrations and bud-break response to exogenous benzyl adenine in shoots of apple trees with two growth habits grown on three rootstocks. Journal Horticultural Science and Biotechnology, 82, 960-966.

Tworkoski, T.; S. Miller \& R. Scorza (2006). Relationship of pruning and growth morphology with hormone ratios in shoots of pillar and standard peach trees. Journal Plant Growth Regulator, 25, 145-155.

Tworkoski, T. \& G. Fazio (2011). Physiological and morphological effects of sizecontrolling rootstocks on "Fuji" scion. Acta Horticulture, 865-872.

Waluya, A. (2011). Pengaruh jumlah mata tunas stek terhadap pertumbuhan empat varietas ubi kayu (Manihot esculenta Crantz). Skripsi. Institut Pertanian Bogor, Bogor. 
Yetisir, H. \& N. Sari (2003). Effect of different rootstock on plant growth, yield and quality of watermelon. Australian Journal of Experimental Agriculture, 43, 1269-1274.

Zheng, N.; M.L. Wang; H.T. Wang \& X.Z. Ai (2009). Effects of grafting on photosynthesis of sweet pepper seedlings under low temperature and weak light intensity. Ying Yong Sheng Tai Xue Bao, 20, 591-596.
Zakariyya, F. \& A.A. Prawoto (2015). Stomatal conductance and chlorophyll characteristics and their relationship with yield of some cocoa clones under Tectona grandis, Leucaena sp., and Cassia surattensis. Pelita Perkebunan, 31, 99-108.

$* * 0 * *$ 